Research Paper

\title{
The Effect of Rice Husk Addition as Additive Materials on the Characterization of Ceramic Membrane and Their Application on Water River Treatment Process
}

\author{
Sisnayati ${ }^{1 *}$, Ria Komala ${ }^{1}$, Retno Suryani ${ }^{1}$ \\ ${ }^{1}$ Chemical Engineering Department, Faculty of Engineering, Tamansiswa University, Jalan Tamansiswa No 261 Palembang, Indonesia, 30126 \\ *Corresponding author: sisnayati@unitaspalembang.ac.id
}

\begin{abstract}
This study aims to study how the effect of adding rice husk additives to the characteristics of ceramic membranes with various variations of membrane-forming component composition in terms of surface morphology and pore size of the membrane produced. This research is expected to be used by the community as an alternative treatment of river water into clean water. In this study, the variables studied were the composition of the membrane constituent namely clay, iron powder and rice husk as an additives. The ceramic membrane was designed in the form of a tube, made from a mixture of clay, iron powder and rice husk with a diameter of 5 $\mathrm{cm}$, an outer diameter of $6 \mathrm{~cm}$, a thickness of $1 \mathrm{~cm}$ and a length of $25 \mathrm{~cm}$. Housing membrane was made of glass fiber with an outer diameter of $9 \mathrm{~cm}$, an inner diameter of $8.5 \mathrm{~cm}$ and a length of $30 \mathrm{~cm}$. Making ceramic membranes were from clay, iron powder and rice husk with a ratio of $87.5 \%, 2.5 \%, 10 \%, 77.5 \%, 2.5 \%, 20 \%$ and $77.5 \%, 2.5 \%, 15 \%$. The river water was treated by flowing to the complete separation process. It was taken every 15 minutes, 30 minutes, 45 minutes, 60 minutes, 75 minutes, 90 minutes. Every sampling, the permeate volume was determined. Permeat events were analyzed for chemical parameters in the form of iron (Fe), Manganese (Mn) and Zinc (Zn). Based on the SEM-EDS analysis on the ceramic membrane produced shows that the membrane was classified in the microfiltration membrane group with a random and asymmetrical pore size and structure. According to the BET analysis on ceramic membranes shows that the best ceramic membrane produced in this study is $\mathrm{C}$ ceramic membrane with a clay composition of $87.5 \% ; 10 \%$ of rice husk; and $2.5 \%$ of iron powder with a pore size of $2.8 \mu \mathrm{m}$ and a large surface area of $45.38 \mathrm{~m} 2 / \mathrm{g}$. The difference in pressure of 2 bars gives the best results in reducing levels of contaminant compounds contained in river water with a percentage of Fe reduction of $92.18 \%, \mathrm{Mn}$ of $89.23 \%$, and $\mathrm{Zn}$ of $99.80 \%$.
\end{abstract}

\section{Keywords}

ceramic membrane, rice husk, river water treatment, clean water production, metals reduction

\section{INTRODUCTION}

Membrane technology is a clean technology that is environmentally friendly. It is expected that with the use of membrane technology for the processing of clean water the results obtained can meet the standards of clean water quality in Indonesia, in accordance with the Decree of the Minister of Health of The Republic of Indonesia No. 907/MENKES/SK/VII/2002. This technology can reduce organic and inorganic compounds that are in water without the use of chemicals in operation. The effort carried out in this study is to make ceramic membranes with rice husk additives and how the additives influence the membrane characterization produced. Membranes produced in this study are expected to be used for water treatment.

The advantage of ceramic membranes lies in their good thermal stability, resistance to chemical compounds, biological degradation or microbes. These properties show superiority when compared to membranes made of polymer compounds and are relatively easy to clean with a cleaning agent. Chemical resistance causes highly used ceramic membranes in food processing, biochemical and pharmaceutical products (Izadpanah and Javidnia, 2012; Amin et al., 2016). The main material used in the manufacture of ceramic membranes is clay because clay has the most stable properties and is most resistant to erosion. For water treatment can reduce iron ion levels in water to $95 \%$. The use of clay in the membrane manufacturing process serves to form and glue the membrane mixture into a hard and rigid lump after the sintering process (Ginting et al., 2012).

Another material used in the manufacture of ceramic membranes is rice husk which is an additive. The requirement of additives for membranes is that they must be burned out (not leaving tar/ash) and can form pores with a smaller composition than the main ingredients (clay). Rice husks are widely found in rural areas, but their use has not been used optimally. So far, 
rice husks are only used as additional ingredients for animal feed and plant fertilizer. If the composition of the iron powder used is $2.5 \%$ it will produce a compressive strength of 22.55 Mpa (Kumar et al., 2014). It is expected that this research will obtain data that can be used to design ceramic membranes as a tool to process river water into clean water.

This membrane technology can reduce organic and inorganic compounds that are in water without the use of chemicals in their operation. Efforts made in this study for the treatment of clean water, are by using ceramic membrane technology made from clay, iron powder and additives from rice husks. The main material used in making this ceramic membrane is clay. Clay has the most stable and most resistant to erosion. For water treatment can reduce levels of iron ions in water to 95\% and arsenic ion levels depend on the Fe/As ratio. Another material used in the manufacture of ceramic membranes is rice husk which is an additive. The requirement of additives for membranes is that they must be burned out (not leaving tar / ash) and can form pores with a smaller composition than the main ingredients (clay). Rice husks are abundant in rural areas, but their use has not been fully utilized. This description is one way to use rice husks to obtain clean water which is a necessity for the community.

Research conducted by Nasir (2013) uses iron powder as an aggregate to strengthen the structure of ceramic membranes. The best composition of the membrane made was clay $67.5 \%$; coal ash $25 \%$; and $7.5 \%$ iron powder. With such composition, membranes are able to reduce TDS by $60.2 \%$; iron $(\mathrm{Fe})$ metal ion is $91.54 \%$ and organic matter content is $84.33 \%$. Kasim et al. (2017) performed manganese removal using filtration techniques using polyamide nanofiltration and ultrafiltration membranes (PA-NF and PA-UF) to treat surface water into drinking water resources. The results showed that $\mathrm{pH}$ in the range 3-11 significantly improved membrane performance in terms of manganese removal. Manganese removal with a feed concentration of $50 \mathrm{mg} / \mathrm{L}$ showed various membrane performance patterns. For NF and UF membranes respectively manganese removal was of $97.2 \%$, and of $99.2 \%$ at $\mathrm{pH} 9$.

Research conducted by Sisnayati (2015) on the manufacture of ceramic membranes using rice husk as an additive to ceramic membranes showed a good membrane performance that is able to reduce the concentration of $\mathrm{Cd}$ metal in the pulp industry wastewater by $99.9 \%$. But the characteristics of the membrane produced were still very fragile. Sisnayati et al. (2017) conducted further research using C-active from OPEFB to treat river water into clean water. Membrane characteristics produced were types of ultrafiltration membranes because of the use of the ballmill process to form ultra-sized pores. From this study it was found that ceramic membrane made from $\mathrm{C}$-active additives of OPEFB being able to detect $\mathrm{Fe}, \mathrm{Mn}$ and $\mathrm{Zn}$ with a very high percentage of reduction, namely Fe of $92.18 \%$, Mn of $82.93 \%$ and $\mathrm{Zn}$ of $99.8 \%$. Increasing of rice husk ash content can increase membrane porosity based on $\mathrm{Al}_{2} \mathrm{O}_{3}$ powder while its mechanical properties will decrease (Ali et al., 2017). Acid treatment from rice husk ash can remove metals and does not affect the silica's morphity (Matori et al., 2009). Liquid waste treatment using ceramic membranes is an environmentally friendly method because it does not require the addition of chemicals and ceramic membranes that are no longer used can be used as materials for making cement stones (Hafez et al., 2017).

The next main ingredient in this study is iron powder which functions as an aggregate. Besides its availability which is abundant in nature and easily treated, iron powder if mixed with other metals will produce a very hard structure. This study aims to study how the effect of adding rice husk additives to the characteristics of ceramic membranes with various variations of membrane-forming component composition in terms of surface morphology and pore size of the membrane produced. This research is expected to be used by the community as an alternative treatment of river water into clean water.

\section{EXPERIMENTAL SECTION}

\subsection{Materials}

Material used in this research were clay, rice husk, iron powder, water, raw river water

\subsection{Methods}

The variables studied were the composition of the membrane constituent. The tools used are 400 mesh size sieves, scales, membrane molds, membrane presses and furnaces, while the materials used are clay, iron powder and rice husk additives.

\subsubsection{Process of Making Ceramic Membrane}

The ceramic membrane was designed in the form of a tube, made from a mixture of clay, iron powder and rice husk with a diameter of $5 \mathrm{~cm}$, an outer diameter of $6 \mathrm{~cm}$, a thickness of 1 $\mathrm{cm}$ and a length of $25 \mathrm{~cm}$. Housing membrane was made of glass fiber with an outer diameter of $9 \mathrm{~cm}$, an inner diameter of $8.5 \mathrm{~cm}$ and a length of $30 \mathrm{~cm}$. Making ceramic membranes were from clay, iron powder and rice husk with a ratio of $87.5 \%$, $2.5 \%, 10 \%, 77.5 \%, 2.5 \%, 20 \%$ and $77.5 \%, 2.5 \%, 15 \%$. The steps to be taken were (1) the clay is thinly sliced, then dried for 2 days, hen puree then sieve using a 400 mesh sieve, (2) iron powder sieved with a 400 mesh sieve, (3) rice husk was pureed and sieved using a 400 mesh sieve, (4) clay, rice husk and iron powder mixed until blended with a ratio of $87.5 \%, 2.5 \%, 10 \%$; $77.5 \%, 2.5 \%, 20 \%$ and $77.5 \%, 2.5 \%, 15 \%$, (5) add water little by little into the mixture of the membrane making material to form a paste (gel) so that it is easily moulded with a ceramic membrane moulding device. After moulding, the mixture was removed from the membrane mold which was then dried at room temperature for 7 days. After drying the membrane was burned (sintering) at $900{ }^{\circ} \mathrm{C}$ for 9 hours.

\subsubsection{Filtration Process}

The river water was put into a storage tank with a capacity of $500 \mathrm{~L}$. Then with the help of a pressurized pump, the river water from the storage tank was flowed to housing- 1 which contains a sponge filter with a pore diameter of $0.5 \mu \mathrm{m}$. Pump 
pressure was set to 1 bar, 1.5 bar and 2 bars by adjusting the feed flow rate using a feed flow meter. Then the filtered river water with a sponge filter of $0.5 \mu \mathrm{m}$ pore diameter was supplied to housing- 2 and housing- 3 , each of which contained a sponge filter with a pore diameter of $0.1 \mu \mathrm{m}$ and activated carbon. Then the river water that has passed through the sponge filter and activated carbon, the river water was flowed again to housing-4 which contains the ceramic membrane that has been made. River water that has passed through the membrane process was accommodated in a container as permeate. Sampling of river water that has passed the complete separation process was taken every 15 minutes, 30 minutes, 45 minutes, 60 minutes, 75 minutes, 90 minutes. Every sampling, the permeate volume was calculated. Permeat events were analyzed for physical parameters in the form of temperature, TDS, and chemical parameters in the form of $\mathrm{pH}$, iron (Fe), Manganese (Mn) and Zinc (Zn).

\section{RESULTS AND DISGUSSION}

3.1 Characteristics of ceramic membranes

3.1.1 Ceramic Scanning Electron Microscopy (SEM) analysis

Ceramic membrane micrograph with clay composition; rice husk; Iron powder in various compositions can be seen in Figures 1, 2 and 3. Rice husk lumps will form bonds with coinciding particles and clearly see the reduction of the pore size of the surface to the inside of the pore. This shows the formation of a microcopy membrane.

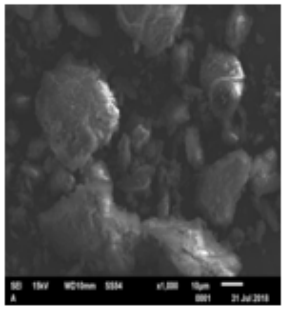

(a)

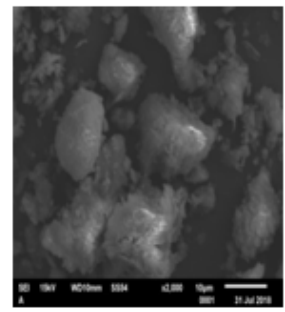

(b)

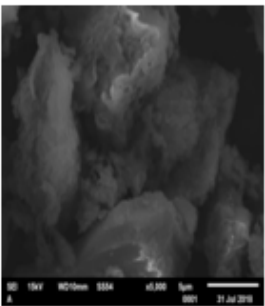

(c)
Figure 1. SEM image of ceramic membrane $\mathrm{A}$ with various magnifications (a) 1000x (b) 2000x and (c) 5000x

According to the results of the SEM test, it was found that the smaller the particle size of a particle from the ceramic membrane, the more reactive and the membrane pores were evenly distributed throughout the membrane surface. Grain size and grain boundary ratio play an important role in the diffusion process. Small granules caused a wider surface area. Surface area played an important role in increasing membrane permeation, namely by reducing grain sizes, the permeability will increase. The reduced size of the granules will expand the membrane surface so that the permeation of the membrane will increase.

SEM images of each membrane at various magnification

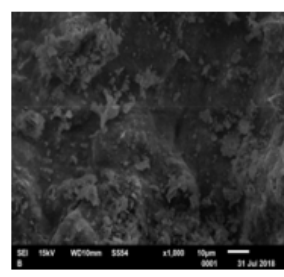

(a)

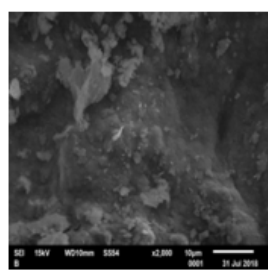

(b)

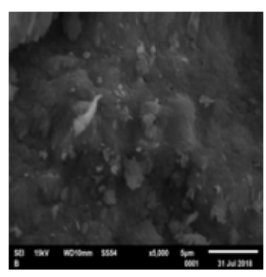

(c)
Figure 2. SEM ceramic membrane $B$ image with various magnifications (a) 1000x (b) 2000x and (c) 5000x

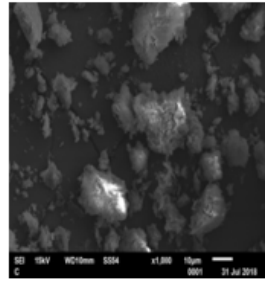

(a)

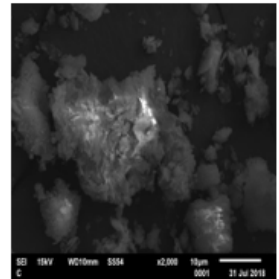

(b)

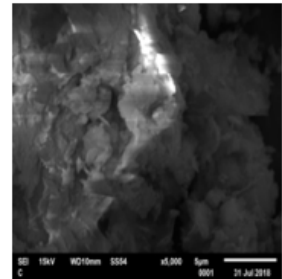

(c)
Figure 3. SEM image of ceramic membrane $\mathrm{C}$ with various magnifications (a) 1000x (b) 2000x and (c) 5000x

variations show that the membrane pore structure was random. Uneven surface pores and texture of the membrane due to the influence of temperature. The picture above shows the pores on the membrane with the addition of rice husks. The more rice husk was added, the more pores that are formed will also look asymmetric.

\subsubsection{Energy Disperse Spectroscopy (EDS) analysis of ce- ramic membranes}

In material testing with Spectrum Energy Disperse Spectroscopy (EDS) for the surface part of ceramic membranes made from rice husks, there were several compounds found in ceramic membranes which can be seen in Table 1 .

From the Figure 1 above, it can be seen the composition of the content of elements contained in membrane A which contains elements of $\mathrm{C}$ with an average mass $\%$ of $19.35 \%$, element $\mathrm{O}$ of $27.59 \%$, elements of $\mathrm{Al}$ at $9.91 \%$, elements of $\mathrm{Si}$ equal to $20,81 \%$, element $\mathrm{K}$ is $0.85 \%$, elemental $\mathrm{Fe}$ is $3.95 \%$. At Membrane $\mathrm{B}$ has the composition of the content of $\mathrm{C}$ with an average mass $\%$ of $8.13 \%$, element $\mathrm{O}$ was of $35.85 \%$, elemental $\mathrm{Al}$ was of $14.94 \%$, elemental $\mathrm{Si}$ was of $23.35 \%$, element $\mathrm{K}$ was of $1.18 \%$, Fe element was of $8.02 \%$, whereas in membrane $\mathrm{C}$ has a composition of element $\mathrm{C}$ content of $29.29 \%$, element $\mathrm{O}$ was of $27.64 \%$, element $\mathrm{Al}$ was of $12.12 \%$, element $\mathrm{Si}$ was of $17.95 \%$, element $\mathrm{K}$ was of $0.90 \%$, element $\mathrm{Fe}$ was of equal to $4.37 \%$. 
Table 1. Analysis of EDS on various types of ceramic membranes from the study

\begin{tabular}{|c|c|c|c|c|c|c|c|c|c|c|c|c|}
\hline \multirow[b]{2}{*}{ Elements } & \multicolumn{3}{|c|}{ Membrane A (\% wt) } & \multirow[b]{2}{*}{ Average } & \multicolumn{3}{|c|}{ Membrane B (\% wt) } & \multirow[b]{2}{*}{ Average } & \multicolumn{3}{|c|}{ Membrane C (\% wt) } & \multirow[b]{2}{*}{ Average } \\
\hline & $\begin{array}{l}\text { Spot } \\
001\end{array}$ & $\begin{array}{l}\text { Spot } \\
002\end{array}$ & $\begin{array}{l}\text { Spot } \\
003\end{array}$ & & $\begin{array}{l}\text { Spot } \\
001\end{array}$ & $\begin{array}{l}\text { Spot } \\
002\end{array}$ & $\begin{array}{l}\text { Spot } \\
001\end{array}$ & & $\begin{array}{l}\text { Spot } \\
001\end{array}$ & $\begin{array}{l}\text { Spot } \\
002\end{array}$ & $\begin{array}{l}\text { Spot } \\
001\end{array}$ & \\
\hline $\mathrm{C}(\mathrm{K})$ & 7.48 & 6.95 & 43.61 & 19.35 & 4.05 & 9.88 & 10.46 & 8.13 & 5.21 & 34.46 & 48.19 & 29.29 \\
\hline $\mathrm{O}(\mathrm{K})$ & 23.41 & 28.54 & 30.82 & 27.59 & 28.24 & 39.67 & 39.65 & 35.85 & 24.48 & 29.24 & 29.19 & 27.64 \\
\hline $\mathrm{Al}(\mathrm{K})$ & 12.78 & 9.42 & 7.53 & 9.91 & 13.49 & 16.15 & 15.18 & 14.94 & 15.78 & 13.42 & 7.15 & 12.12 \\
\hline $\mathrm{Si}(\mathrm{K})$ & 27.40 & 19.75 & 15.29 & 20.81 & 22.48 & 23.89 & 23.67 & 23.35 & 24.82 & 16.67 & 12.37 & 17.95 \\
\hline $\mathrm{K}(\mathrm{K})$ & 1.54 & 1.02 & - & 0.85 & 0.90 & 1.17 & 1.47 & 1.18 & 1.70 & 1.01 & - & 0.90 \\
\hline $\mathrm{Fe}(\mathrm{K})$ & 4.46 & 4.63 & 2.75 & 3.95 & 5.93 & 8.56 & 9.57 & 8.02 & 4.82 & 5.19 & 3.10 & 4.37 \\
\hline
\end{tabular}

3.1.3 The Brenuaer-Emmet-Teller (BET) analysis of ceramic membranes

In this study using three membranes with different compositions. The first membrane was a membrane with of $77.5 \%$ clay composition, $20 \%$ rice husk and $2.5 \%$ iron powder. The second membrane (B) has $82.5 \%$ clay composition, $15 \%$ rice husk and $2.5 \%$ iron powder and the third membrane $(\mathrm{C})$ was a membrane with clay composition of $87.5 \%, 10 \%$ rice husk and iron powder $2.5 \%$. The purpose of BET analysis was to determine the pore size, porosity and surface area.

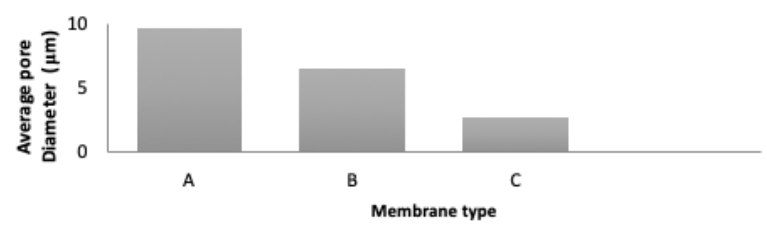

(a)

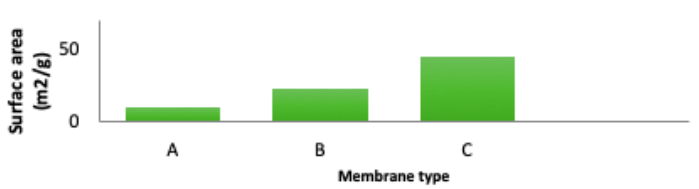

(b)

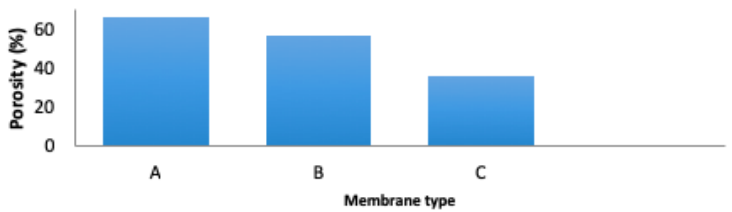

(c)

Figure 4. Membrane type versus (a) average membrane pore diameter; (b) membrane surface area; (c) membrane porosity

From the Figure 4 above, the pore size of membrane di- ameter $\mathrm{A}$ is $9.7 \mu \mathrm{m}$ while the pore size of membrane $\mathrm{B}$ and $\mathrm{C}$ is $6.5 \mu \mathrm{m}$ and $2.8 \mu \mathrm{m}$ respectively. The characteristics of the ceramic membrane used for this research were the type of microfiltration membrane. The surface area of membrane A is smaller than the surface area of membrane B and $\mathrm{C}, \mathrm{w}$ hile the porosity of membrane $\mathrm{A}$ is greater than the porosity of membrane $\mathrm{B}$ and $\mathrm{C}$ or in other words it appears that there is a decrease in membrane surface area with a decrease in the composition of rice husks. This may be because during high temperature sintering, the structure of rice husk coincides. With too little rice husk that results in the formation of very small pores resulting in a higher surface area. Porosity decreases according to the reduction of rice husk additives contained in the membrane. By using more and more additives, it will increase the porosity of the ceramic membrane. (Sari et al., 2012). Based on the results of the analysis in terms of the pore size and surface area of the membrane produced in this study, the best composition of ceramic membrane can be determined, namely membrane $\mathrm{C}$ with clay composition of $87.5 \%$, rice husk of $10 \%$ and iron powder of $2.5 \%$. It is expected that the smaller the membrane pore and the large surface area will be able to inhibit the material/pollutant particles in a larger amount.

\subsection{Analysis of Membrane Performance 3.2.1 Permeat Flux Analysis}

The optimal membrane performance can generally be expressed by permeate flux, the amount of permeability, membrane selectivity to certain chemical compounds and the magnitude of the percentage rejection of unwanted compounds in the feed, the greater the value of permeability and the level of selectivity of a membrane, and the better the performance of the membrane.

In this study, the values of membrane fluxes for Gasing River were obtained at 1 bar transmembrane pressure, 1.5 bar and 2 bars (Figure 5). The highest flux value at 2 bar pressure after the membrane was operated for 15 minutes was $32.10 \mathrm{x}$ $102 \mathrm{~L} / \mathrm{m}^{2}$. The lowest flux after the membrane was operated for 90 minutes at 1 bar pressure was $3.48 \times 102 \mathrm{~L} / \mathrm{m}^{2}$. The 
decrease in flux value was caused by the solute and was retained by the filter. It will accumulate over time or accumulate on the surface of the membrane and cause the formation of gel or fouling layer on the surface of the membrane, resulting in compression and increased resistance on the membrane surface. The effect of pressure and operating time on the permeate flux shown in Figure 5. This Figure 5 shows that permeate fluxes increase with increasing operating pressure. This is consistent with the driving force of the membrane operation. The pressure applied to the flow of feed through the membrane will result in a smaller flow of fluid with particle size than the membrane pore can pass through the membrane, while larger particles such as contaminants will survive. In addition, the magnitude of the thrust given results in an increase in the size of the membrane pore, so that the rate of the feed solution is faster and more and more passing through the membrane.

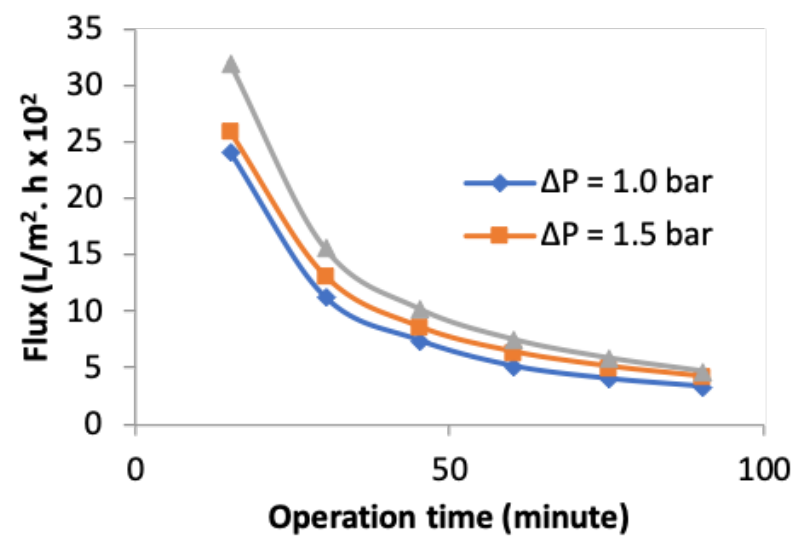

Figure 5. Gasing River Permeat Flux at various time and operating pressures

\subsubsection{Analysis of the concentration of water quality param- eters in the Gasing River}

Membranes can also be determined by their ability to reduce the concentration of contaminant compounds. The following is the quality of permeate (see the decrease in the concentration of $\mathrm{Fe}, \mathrm{Mn}$, and $\mathrm{Zn}$ ) with the operation of ceramic A membrane based on $77.5 \%$ of clay; $20 \%$ of rice husks and $2.5 \%$ of iron powder with a pressure variation of 1 bar, 1.5 bar and 2 bars (Figure 6)

In this study feed from Sungai Gasing has Fe content of $1.08 \mathrm{mg} / \mathrm{L}$. The Figure 6 above illustrates the decrease in $\mathrm{Fe}$ content in Gasing river water, during operation for 15 minutes at $1 \mathrm{bar}$ pressure has a $\mathrm{Fe}$ content of $0.23 \mathrm{mg} / \mathrm{L}$ with a rejection percentage of $77.23 \%$ and the smallest $\mathrm{Fe}$ content after operating for 90 minutes at pressure 2 bar with a value of 0.14 $\mathrm{mg} / \mathrm{L}$, with a percentage of Fe rejection of $86.14 \%$. Decrease in Fe content in permeate for river water has experienced a decrease in $\mathrm{Fe}$ content which is quite good, on average above $50 \%$ and some even reach $86 \%$.

In Figure 7 the Mn content in the Gasing river feed was of

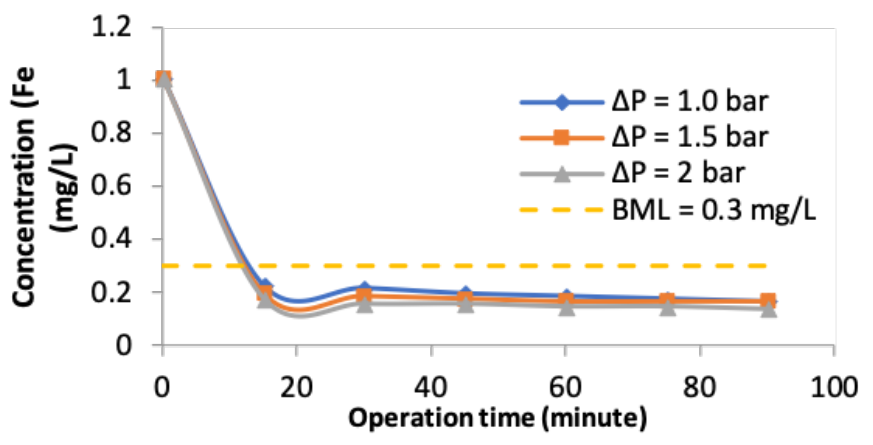

Figure 6. Fe concentration in the Gasing River at various time and operating pressures

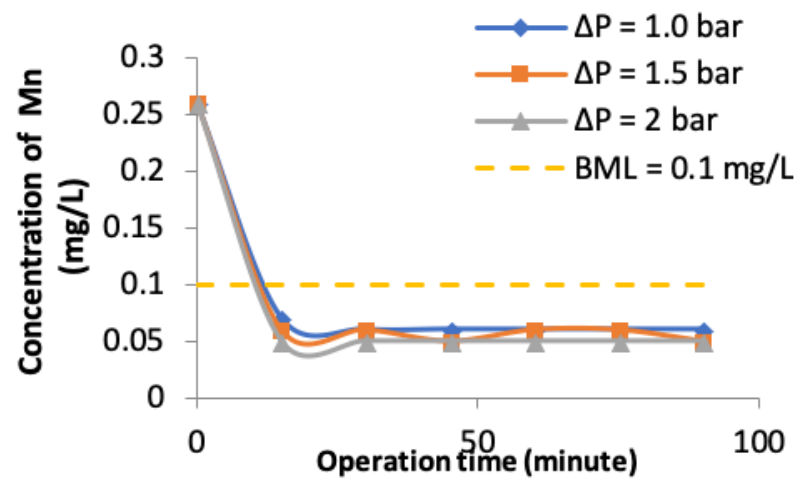

Figure 7. Mn concentration in the Gasing River in various time and operating pressures

$0.3 \mathrm{mg} / \mathrm{L}$, greather than environmental quality standard $(0.1$ $\mathrm{mg} / \mathrm{L}$ ). After operation with the membrane for 15 minutes the pressure of $1 \mathrm{bar}$, the concentration of $\mathrm{Mn}$ was $0.07 \mathrm{mg} / \mathrm{L}$ with the smallest Mn rejection percentage of $73.08 \%$. In the graph above the greatest decrease in permeate concentrations occurs starting at 1.5 bar with 90 minutes operating time up to 2 bar pressure starting from 15 minutes to 90 minutes at $0.05 \mathrm{mg} / \mathrm{L}$ with a percentage of Mn rejection of $80.77 \%$.

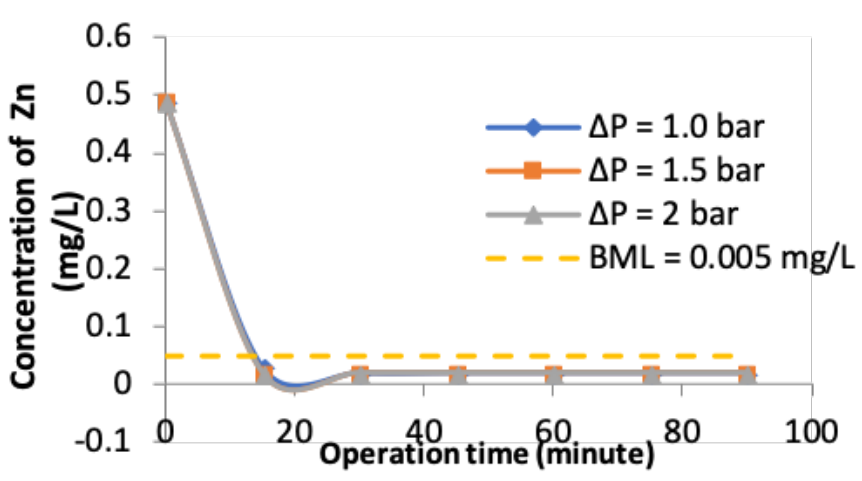

Figure 8. Zn concentration in the Gasing River at various time and operating pressures

The $\mathrm{Zn}$ content in the Gasing river feed is $0.59 \mathrm{mg} / \mathrm{L}$ past 
the standard limit of $0.05 \mathrm{mg} / \mathrm{L}$. In Figure 4 . after operation with a pressure of 1 bar for 15 minutes has a $\mathrm{Zn}$ content of 0.03 $\mathrm{mg} / \mathrm{L}$ with the smallest percentage rejection of $93.88 \%$ and has the smallest $\mathrm{Zn}$ content at the pressure of 1 bar for 30 minutes to a pressure of 2 bar for 90 minutes namely amounting to $0.02 \mathrm{mg} / \mathrm{L}$. The highest percentage of $\mathrm{Zn}$ rejection is $99.80 \%$.

From Figures $6-8$, the percentage of rejection for each contaminant $(\mathrm{Fe}, \mathrm{Mn}$, and $\mathrm{Zn}$ ) increases with increasing pressure and operating time. This is due to the concentration polarization. Concentration polarization occurs due to the accumulation of substances or particles that are held back by the membrane resulting in accumulation and increased concentration above the membrane surface. With the higher concentration of contaminants, the greater the concentration of contaminants in the ceramic membrane wall will further inhibit the flow rate of the feed passing through the membrane (Romero et al., 2014). Besides that, the higher pressure applied to the feed flow will be more and more contaminant particles with large size are blocked in the membrane wall and will result in smaller particle flow through the membrane pore, so the concentration of contaminants in the permeate will be smaller. Thus the percentage of contaminant rejection will be even greater.

\subsubsection{Percentage of river water treatment rejection of Gas- ing into clean water}

The results of Gasing river water analysis can be seen in Table 2 below.

From the Table 2 above, it can be seen that the initial feed contaminants that exceed the Environmental Quality Standards are $\mathrm{pH}, \mathrm{Fe}, \mathrm{Mn}$, and $\mathrm{Zn}$. In the initial feed there was an increase in $\mathrm{pH}$ from 5.6 at the outlet of the activated carbon filter to 6.7 at the ceramic membrane filter outlet. The Fe concentration at the beginning of the feed exceeds the environmental quality standard, which is $1.01 \mathrm{mg} / \mathrm{L}$ and the concentration decreases to $0.079 \mathrm{mg} / \mathrm{L}$ with a rejection percentage of $92.18 \%$. Mn concentration also decreased with an initial concentration of $0.26 \mathrm{mg} / \mathrm{L}$ to $0.028 \mathrm{mg} / \mathrm{L}$ with a rejection percentage of $89.23 \%$. Zn concentration experienced a concentration reduction of $0.049 \mathrm{mg} / \mathrm{L}$ to $0.003 \mathrm{mg} / \mathrm{L}$ with a rejection percentage of $99.80 \%$. This is because the contaminants are filtered or obstructed on the surface of the membrane wall so that the resulting concentration meets the Environmental Quality Standards.

\subsection{Scanning Electron Microscope (SEM) and Energy Dis- perse Spectroscopy (EDS) analysis after being used for River Water Treatment}

Analysis of SEM and EDS after the treatment process needs to be done again because to determine the surface morphology of the membrane so that it can know and convince this study that the membrane can work to inhibit contaminant compounds that enter through the membrane wall. Ceramic membranes analyzed are $\mathrm{C}$ ceramic membranes that have been used to treat Gasing River water at 2 bar pressure. This is because at 2 bar operating pressure the highest concentration decrease occurs.

From the SEM observation, it was seen that the pores were closed and the texture of the membrane surface which was increasingly uneven due to blockage by contaminant compounds. This indicates that the phenomenon of polarization concentration on the membrane wall, where contaminant compounds will be inhibited on the membrane wall and resulted in concentrations of contaminants will be thicker on the surface of the membrane wall, and conversely the permeate concentration that passes through the membrane will be smaller, so the percentage of permeate reduction will be greater.

In the Table 3 above shows that there are elements contained in ceramic $\mathrm{C}$ membrane after being used for processing river water into clean water. namely Fe with a mass\% of $16.35 \%$. $\mathrm{Zn}$ is $2.40 \%$ and $\mathrm{Mn}$ is $10.29 \%$. This shows that the heavy metals which are elements of river water contaminants which can be inhibited by the ceramic $\mathrm{C}$ membrane used in this study. This is in accordance with the theory of concentration polarization. where the contaminant compound will be concentrated on the membrane wall so that the resulting permeate will be less concentrated and will increase the reduction value. This also proves that the increase in transmembrane pressure that works in the filtration process will reduce the permeate concentration caused by concentration polarization and vice versa. This will increase the percentage of contaminant reduction. Pair element C. O. Al. K. Au and Si decreased the percentage of mass resulting from the addition of new elements in the ceramic membrane.

\section{CONCLUSIONS}

SEM-EDS analysis on the ceramic membrane produced shows that the membrane was classified in the microfiltration membrane group with a random and asymmetrical pore size and structure. Based on EDS analysis shows that ceramic membranes from rice husk additives contain elements of C (48.19\%), $\mathrm{O}(29.19 \%), \mathrm{Al}(7.15 \%), \mathrm{Si}(12.37 \%)$ and $\mathrm{Fe}(3,10 \%)$. Addition of clay will increase the mass of oxygen and aluminum.

BET analysis on ceramic membranes produced shows that the best ceramic membrane produced in this study is $\mathrm{C}$ ceramic membrane with a clay composition of $87.5 \%$; $10 \%$ of rice husk; and $2.5 \%$ of iron powder with a pore size of $2.8 \mu \mathrm{m}$ and a large surface area of $45.38 \mathrm{~m}^{2} / \mathrm{g}$.

The rejection percentage for each contaminant $(\mathrm{Fe}, \mathrm{Mn}$ and $\mathrm{Zn}$ ) increases with increasing pressure and operating time. The difference in pressure of 2 bars gives the best results in reducing levels of contaminant compounds contained in river water with a percentage of Fe reduction of $92.18 \%$, Mn of $89.23 \%$, and $\mathrm{Zn}$ of $99.80 \%$.

\section{ACKNOWLEDGEMENT}

We would like to thank Kemenristekditi for the financial support so that the research has been realized. 
Table 2. Results of analysis of Gasing River Water

\begin{tabular}{ccccccccc}
\hline Parameter & Unit & Initial & SF-I & SF-II & ACF & CM & $\% \mathrm{R}$ & Std $^{*}$ \\
\hline Iron $(\mathrm{Fe})$ & $\mathrm{mg} / \mathrm{L}$ & 1.08 & 1.01 & 1.01 & 1.01 & 0.079 & 92.18 & 0.3 \\
Manganesse $(\mathrm{Mn})$ & $\mathrm{mg} / \mathrm{L}$ & 0.3 & 0.26 & 0.26 & 0.26 & 0.028 & 89.23 & 0.1 \\
Zink (Zn) & $\mathrm{mg} / \mathrm{L}$ & 0.59 & 0.51 & 0.49 & 0.49 & $<0.003$ & 99.8 & 0.005 \\
\hline
\end{tabular}

Notes : SF -01 : spon filter Size $5 \mu \mathrm{m}$; SF-02 : spon filter size $1 \mu \mathrm{m}$; ACF : Activated Carbon Filter ; CM : Ceramic Membran; Std : Standard based on South Sumatera Province Governor Regulation; * No. 16 Year 2005

Table 3. Comparison of membrane C elements before and after use to treat river water into clean water

\begin{tabular}{lccccc}
\hline \multirow{2}{*}{ Elements } & Before & \multicolumn{2}{c}{ After treatment } & & \\
& Treatment & spot -1 & spot -2 & spot -3 & Average \\
\hline $\mathrm{C}$ & 29.29 & 17.63 & 14.8 & 37.89 & 23.44 \\
$\mathrm{O}$ & 27.64 & 20.82 & 31.85 & 24.93 & 25.87 \\
$\mathrm{Al}$ & 12.12 & 6.12 & 7.15 & 1.71 & 4.99 \\
$\mathrm{Si}$ & 17.95 & 16.23 & 11.78 & 6.38 & 11.46 \\
$\mathrm{~K}$ & 0.9 & - & - & - & - \\
$\mathrm{Fe}$ & 4.37 & 15.23 & 15.95 & 17.87 & 16.35 \\
$\mathrm{Au}$ & 7.73 & 15.41 & - & - & 5.14 \\
$\mathrm{Mn}$ & - & 7.12 & 15.69 & 8.05 & 10.29 \\
$\mathrm{Zn}$ & - & 1.25 & 2.78 & 3.17 & 2.4 \\
\hline
\end{tabular}

\section{REFERENCES}

Ali, M., M. Hanim, S. Tahir, C. Jaafar, N. Mazlan, and K. Matori (2017). The Effect of Commercial Rice Husk Ash Additives on the Porosity, Mechanical Properties, and Microstructure of Alumina Ceramics. Advances in Materials Science and Engineering; 1-10

Amin, S., H. Abdallah, M. Roushdy, and S. El-Sherbiny (2016). An Overview of Production and Development of Ceramic Membranes. International Journal of Applied Engineering Research, 11(12); 7708-7721

Ginting, J., A. Budi, and E. Budi (2012). Penggunaan Membran Keramik Berbasis Zeolit dan Clay dengan karbon Aktif Sebagai Aditif Untuk Penurunan Kadar Fe dan Mn Pada Air Tanah Daerah Bekasi. In Seminar Nasional Fisika

Hafez, A., M. Khedr, M. Mohammed, R. Sabry, and R. Osman (2017). Utilization Of Rice Husk Ash And Ceramic Wastes In Manufacturing Of Developed Cement Bricks. ARPN Journal of Engineering and Applied Sciences, 12(9); 28542862

Izadpanah, A. and A. Javidnia (2012). The Ability of Nanofiltration Membrane to Remove Hardness and Ions from Diluted Seawater. Water, 4; 283-294

Kasim, N., A. Mohammad, and S. Abdullah (2017). Iron and Manganese Removal by Nanofiltration and Ultrafiltration Membranes: Influence of pH Adjusment. Malaysian Journal of Analytical Sciences, 21(1); 149-158

Kumar, B., R. Suhas, S. Shet, and J. Srishaila (2014). Utiliza- tion of Iron Ore Tailings as Replacement to Fine Agregates in Cement Congrete Pavements. International Journal of Research in Engineering and Technology, 3(7); 369-376

Matori, K., M. Haslinawati, Z. Wahab, H. Sidek, T. Ban, and W. Ghani (2009). Producing Amorphous White Silica from Rice Husk. MASAUM Journal of Basic and Applied Sciences, 1(3); 512-515

Nasir, S. (2013). Treatment of Domestic Water Using Ceramic Filter from Natural Clay and Fly Ash. Journal of Engineering Studies and Research, 19(3); 71-75

Romero, V., V. Vega, J. Garcia, V. Prida, and B. Hernando (2014). Effect of Porosity and Concentration Polarization on Electrolyte Diffuse Transport Parameters through Ceramic Membranes with Similar Nanopore Size. Nanomaterials, 4; $700-711$

Sari, E., S. Agus, and B. Esmar (2012). Pengaruh Aditif Arang Batok Kelapan Terhadap Densitas dan Porositas Membran Keramik Berbasis Zeolit dan Tanah Lempung. Seminar Nasional Fisika; 67-71

Sisnayati (2015). Penurunan Cadmium Dari Limbah Cair Industri Pulp Menggunakan Membran Keramik Berbahan Aditif Dedak Padi. Kinetika, 6; 37-43

Sisnayati, M. Said, S. Nasir, and D. Priadi (2017). The Effect of Addition of Activated Carbon Made From Palm Empty Fruit Bunch and Iron Powder on Ceramic Membrane Characteristics. Proceeding Book The 7th Annual Basic Science International Conference, 2; 101-104 